\title{
Partner Selection in Supply Chain of Vietnam's Textile and Apparel Industry: The Application of a Hybrid DEA and GM $(1,1)$ Approach
}

\author{
Chia-Nan Wang, ${ }^{1,2}$ Han-Khanh Nguyen, ${ }^{1}$ and Ruei-Yuan Liao ${ }^{3}$ \\ ${ }^{1}$ Department of Industrial Engineering and Management, National Kaohsiung University of Applied Sciences, \\ No. 415 Chien Kung Road, Sanmin District, Kaohsiung City 80778, Taiwan \\ ${ }^{2}$ Department of Industrial Engineering and Management, Fortune Institute of Technology, Kaohsiung 83160, Taiwan \\ ${ }^{3}$ National Sun Yat-sen University, Kaohsiung 80424, Taiwan
}

Correspondence should be addressed to Han-Khanh Nguyen; nguyenhankhanh@gmail.com

Received 2 July 2017; Revised 25 September 2017; Accepted 10 October 2017; Published 8 November 2017

Academic Editor: Emilio Jiménez Macías

Copyright (c) 2017 Chia-Nan Wang et al. This is an open access article distributed under the Creative Commons Attribution License, which permits unrestricted use, distribution, and reproduction in any medium, provided the original work is properly cited.

\begin{abstract}
Vietnam is currently among the top-five textile and apparel exporters, and the industry is considered quite attractive to foreign investors. Nevertheless, the global textile and garment industry is experiencing important changes. The three main producing regions in the world are China, Southwest Asia (India, Pakistan, Bangladesh, and Turkey), and ASEAN. In order to maintain its positioning and to establish stable and sustainable Vietnam textile and apparel development, there must be radical changes. Due to this necessity, the authors conducted this study by using grey forecasting to predict and reflect the condition of businesses in the period of 2017-2020, together with combining a DEA model to help businesses select the most appropriate strategic partner in the supply chain in order to achieve economic goals and promote the strength of the businesses partaking in the association. Besides, this helps businesses exploit market opportunities and take advantage of the capabilities of the textile and apparel industry.
\end{abstract}

\section{Introduction}

1.1. Overview of Vietnam's Textile and Apparel Industry. After more than 20 years of continuous development with an average growth rate at $17 \%$ per year, the textile and apparel industry has become a major economic industry and is a leading export industry in Vietnam, accounting for 10\%-15\% gross domestic product (GDP) [1]. By the end of 2014, there were 5,214 textile and apparel companies in Vietnam with the majority of those being small- and medium-sized companies. The textile and apparel work force occupied more than $20 \%$ of the nation-wide work force and nearly $5 \%$ of the nation-wide work force. Garment companies accounted for the largest share (84\%), followed by textile and spinning companies $(15 \%)$. Vietnam was one of the top 10 textile exporters in the world with the market share at $3.1 \%$ in 2014 . The country's main export markets included the United States, European Union (EU), Japan, and Korea (85\% of the total export goods), providing the garment for mostly the low and middle classes (see Table 1). Although foreign direct investment (FDI) enterprises represented only $25 \%$ in the volume, they contributed to more than $65 \%$ of Vietnam's export turnover [2].

Currently, Vietnam is involved in the process of the lowest value-added, that is, the "cut-make-trim" with the simple outworks production method (the "cut-make-trim" comprises 85\%; see Table 2). Vietnam's garment sector still depends on imported raw materials $(70 \%-80 \%)$, mainly from China, Taiwan, and Korea. The size of the Vietnamese textile and apparel market is limited at only $\$ 3$ billion, and per capita expenditures for the textile and apparel are rather low [2]. Also, the Vietnamese garment enterprises are encountering difficulties in occupying the domestic market, as those companies have to compete with fake and nonquota imported goods. Branding includes just a few small and successful firms; the majority of Vietnamese textile and apparel enterprises are inadequate in absorbing knowledge such as building distribution systems, design, and branding. 
TABLE 1: Main export markets of Vietnam's textile and apparel in 2016.

\begin{tabular}{llc}
\hline Nation & \multicolumn{1}{c}{ Unit } & Value \\
\hline United States of America & Billions of U.S Dollars & 11.45 \\
Japan & Billions of U.S Dollars & 2.9 \\
Korea & Billions of U.S Dollars & 2.284 \\
China & Millions of U.S Dollars & 825 \\
Germany & Millions of U.S Dollars & 726.2 \\
England & Millions of U.S Dollars & 715 \\
Holland & Millions of U.S Dollars & 538 \\
\hline
\end{tabular}

Sources: [14].

Free trade agreements, such as the Vietnam-Korea Free Trade Agreement (VKFTA), European Union-Vietnam Free Trade Agreement (EVFTA), and Trans-Pacific Partnership Agreement (TPP), open up many opportunities for the export turnover growth in Vietnam's textile and apparel industry. The industry is expected to reach $\$ 50-\$ 55$ billion in 2025 thanks to FTA [2]. On the other hand, Vietnam has to face many difficulties and challenges in obeying origin rules, labor standards, strict social responsibilities, eco labels, environmental protection, and so on. Currently, Vietnam is relying on the supply of main fabrics and fibers from China and Taiwan; those that are not in the TPP. Thus, when the agreements come into force, Vietnam may have little chance to inherit tax incentives. The textile and apparel industry with the majority of small- and medium-sized companies having low financial capacity and competitiveness will experience difficulties when the economy is opened. Hence, in order to promote the overall strength of the industry, the implementation of coalition among textile enterprises has to be driven in force for the enterprises to complete and move up to a higher value chain, aiming to gain benefits from alliances, for example, achieving economies of scale; reducing production costs and transaction costs; increasing access to technology, new production resources, and markets; leveraging negotiation position and competitiveness; improving the organizational and knowledge capacity through the sharing of experience within coalition group; and building risk reduction. Joining alliances is to better serve the market. It is the only way for new textile and apparel enterprises to provide a large number of products with consistent quality and timely delivery for many partners and integrate deeper and wider into the world economy.

1.2. Global Textile and Apparel Value Chain. Gereffi introduced the global textile and apparel value chain in 2002 [3]. Whereby the textile and apparel value chain is affected by purchasers, creating finished products must go through many stages, and production activities are often carried out in many countries. In particular, well-known manufacturers, big wholesalers, and retailers play key roles in establishing production networks and shaping mass consumption through a series of strong brands and outsourcing activities to satisfy this demand. The global textile and apparel value chain is divided into five basic stages: (1) supply of raw materials, including natural cotton, thread, and so on; (2) production of intermediate goods; products of this stage are fibers and fabrics provided by weaving, knitting, and dyeing companies; (3) design and manufacture of finished products implemented by garment companies; (4) export by commercial intermediaries; (5) marketing and distribution [3]. (See Figure 1.)

In order to study and present the context of the whole supply chain, more research is required. Within this study, we feature an in-depth study of consumer products for textile companies and suppliers for apparel companies. Moreover, this study is mainly focused on partner selection, which is just a part of the supply chain.

1.3. Literature Review. In 1989, Deng introduced the grey system theory, which is an interdisciplinary scientific area and has become quite common in systems to process and predict partially unknown parameters [4]. The grey model (GM) can estimate the behavior under grey system theory in the future based on a limited amount of available data. The GM $(1,1)$ is one of the most important parts of grey system theory and is considered to be the core of the grey prediction model. The advantage of this model is that it can be used when the amount of data is insufficient to perform statistical analysis methods. It requires only a small amount of data and random sample data to calculate and produce the forecast results. Many studies have applied the grey system. For example, in 1989, Bunn conducted a study about forecasting with more than one model [5]. In 2001, Chen et al. studied application of an innovative combined forecasting method in power [6]. In 2005, Yamaguchi et al. studied new grey relational analysis for finding the invariable structure and its applications [7]. In 2009, Lingbin et al. used the grey theory model to predict the number of international tourists in China [8]. Besides, some researchers have conducted strategic alliance studies. For example, Büyüközkan et al. (2008) provided a decision support to make a careful assessment of an elogistics partner [9]. This research proposed a multicriteria decision-making approach to effectively evaluate e-logistics based on strategic alliance partners. Candace et al. (2011) affirmed strategic alliances as an efficient means to access the resources needed for innovation in dynamic environments [10]. Several researches used hybrid DEA (data development analysis) and GM (1,1) to study strategic alliance, which revealed high reliability. This was a complementary concept, which assumed that two complementary companies to be good partners could make an alliance and perform better business. Because this method can estimate the behavior of data in the future based on a limited amount of available data, this complementary concept appeared in the hybrid DEA and GM $(1,1)$ to study strategic alliance for the electronic manufacturing service industry [11]. In 2016, Wang et al. used DEA and a grey theory model to analyze the selection strategic alliance partner in the automobile industry [12]. In 2017, Wang and Nguyen used the grey and DEA model to study enhancing urban development quality based on the results of appraising efficient performance of investors in Vietnam [13].

Strategic alliances between organizations are now ubiquitous; it has been used in the past for enterprises that have 
TABLE 2: Overview of Vietnam's textile and apparel industry.

\begin{tabular}{|c|c|c|}
\hline Indicators & Unit & Value \\
\hline Number of companies & Companies & 6.000 \\
\hline Enterprise scale & People & SMEs of $200-500+$ Account for a large proportion \\
\hline Company structure based on ownership & & Private (84\%), FDI (15\%), State-owned (1\%). \\
\hline Company structure based on operation & & $\begin{array}{c}\text { Sewing (70\%), spinning (6\%), weaving/knitting (17\%), dying (4\%), } \\
\text { ancillary industries (3\%) }\end{array}$ \\
\hline Geographical allocation of company & & North (30\%), Central and plateau (8\%), South (62\%). \\
\hline Number of employees & People & 2,5 Million \\
\hline Average income per worker & VND & 4,5 Million \\
\hline Number of working days per week & Day & 6 \\
\hline Number of hours worked per week & Hour & 48 \\
\hline Number of shifts per day & Shift & 2 \\
\hline Value of textile export in 2016 & US\$ & 23.841 Billion \\
\hline Method of production & $\%$ & Cut - Make - Trim: $85 \%$; others: $15 \%$ \\
\hline
\end{tabular}

Sources: [2].

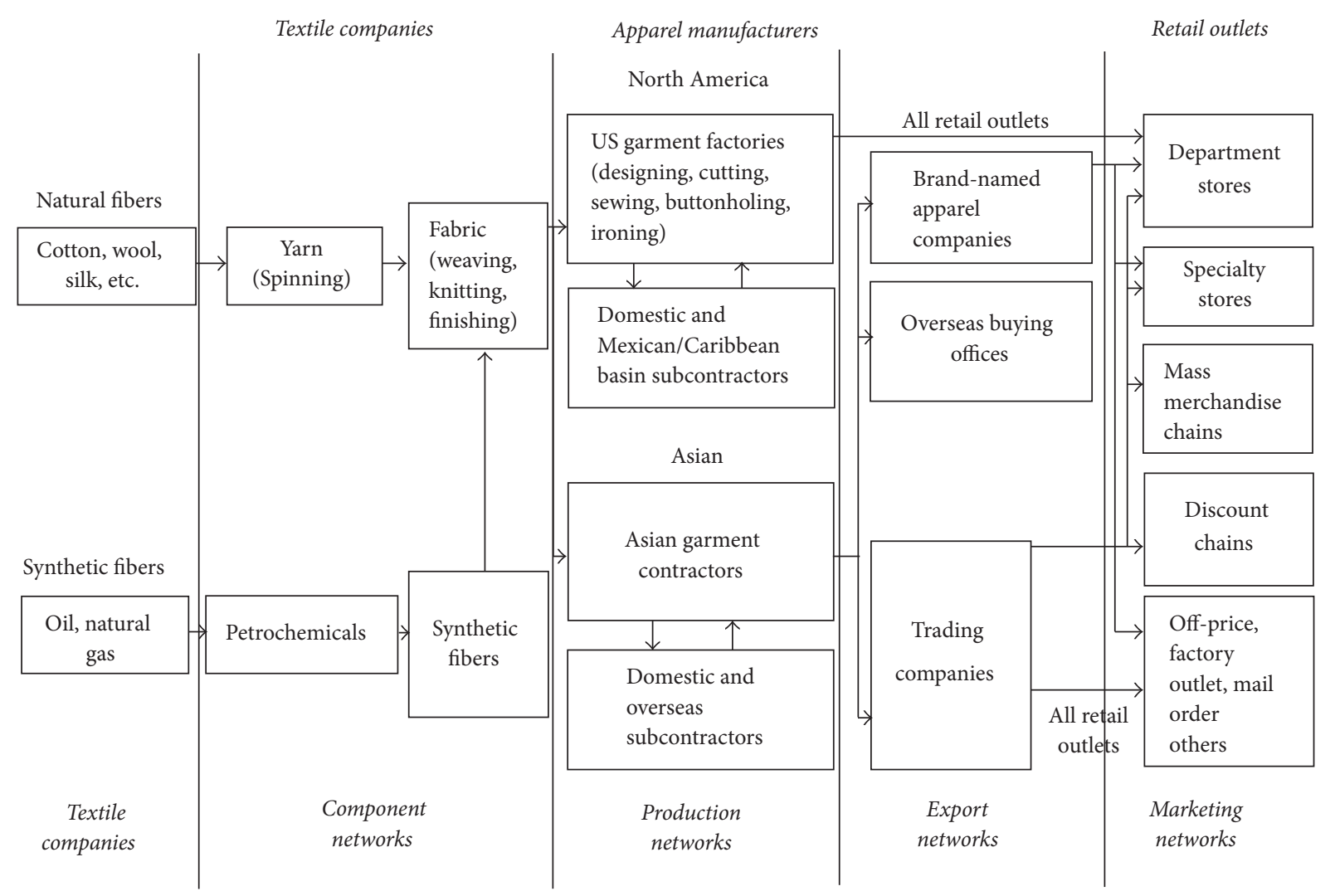

Figure 1: Global textile and apparel value chain [3].

the same expertise and targets. In the current economy of integration and development, along with the limited capacity of enterprises, the technology has not been developed nor has it met the quality and quantity requirements of partners who continue to operate individually; thus, they will encounter difficulties when facing competitors. If we combine each other's strengths, we will create a value chain in each product line, offer prestigious and quality products, and enhance competitiveness in the domestic and international markets.
Therefore, strategic alliances between enterprises are urgent. Thus, combining a hybrid DEA model and grey system theory helps us to choose the strategic alliance for textile and apparel enterprises to make the best of their business goals and possibly exploit the opportunities of the environment, address challenges, and take advantage of the capacity of the textile and apparel industry in Vietnam. This study proposes an effective new method. Through the realities in Vietnam's textile and apparel industry, we would recommend finding 
TABLE 3: List of Companies in textile and apparel industry.

\begin{tabular}{lcc}
\hline Order & DMUs & Companies name \\
\hline 1 & DMU1 & Hue Textile Garment Joint Stock Company \\
(J.S.C)
\end{tabular}

Source: synthetic by researcher [15-29].

the alliance partners for companies to solve those existing problems that they cannot overcome when doing business by using grey theory GM $(1,1)$ to predict what would happen about their business situation in the period 2017-2020. After that, we use a DEA model to evaluate ranking and score of all decision-making units (DMU) in 2016. Combining analytical results from super-SBM model, we put out analysis; alliance suggests bringing high economic efficiency for enterprises as well as Vietnam's textile and apparel industry.

\section{Materials and Methods}

2.1. DMUs Collection. After researching Vietnam's textile and apparel industry, this study reveals 15 companies collected from the General Statistics Office's website [15-29]. We did not choose other enterprises because of this reason: the company scale is small, the uptime does not align with the data requirements, and the business data of those companies do not match with the demand of grey theory model that we used in this research. The synopsis is shown in Table 3.

2.2. Inputs/Outputs Collection. The inputs/outputs element will directly affect the results of the analysis and evaluation. From the literature review, this research summarizes finance factors that were not previously considered. This study carefully selects four inputs and two outputs, which are collected from financial statements of 15 DMUs.

(i) Input factors include the following:

Total assets (TA), which reflect the entire value of existing assets of the business in reporting.

Cost of sold capital (CS), which is the total input cost of the enterprise to produce products, including the cost of inputs, fuel costs, machinery, direct labor, and other expenses.

Selling expenses (SE), which include all costs incurred in the process of consuming products, goods, or services.

General and administration expenses (AE), which are the total costs of business management, administrative management, and other general services related to the operation of the business.

(ii) Output factors include the following:

Revenue of sales (RS), which reflects sales and services revenue of the enterprise in an accounting period of production and business activities from transactions, sales, and servicing operation.

Profit after tax (PT), which reflects the total net profit after tax relating to the enterprise's business activities.

The selected factors reflect wholly a firm's assets, costs, and profits, which can be used as the foundation for analysis, calculation, and evaluation of this study. Researcher synthetics are shown in Tables 4, 5, 6, and 7 .

2.3. Research Development. The authors use the GM $(1,1)$ model to predict the business situation of all DMUs and the super-SBM-I-V model to select strategic alliance partners for the textile business in the future. The process of conducting this study is shown in Figure 2.

Step 1 (objectives identification). Based on the requirements of professional, managerial, and practical needs of the textile and apparel industry, the authors select the objectives of the study.

Step 2 (literature review). By researching and exploring the chosen topic, the authors examine available resources, identifies research purposes, and develops hypothesis for his/her research topic to implement the research. If the topic, time, and method overlap with another study, the authors revert to Step 1.

Step 3 (methodology).

Prediction Method. There are many prediction methods, and the authors use the GM $(1,1)$ to predict the data from the DMUs from 2017 to 2020 because this is a highly reliable prediction method and suitable with the data of DMUs.

DEA Models. There are many methods to choose an alliance partner, and the authors use the super-SBM-I-V, a method of choosing the right strategic alliance partner and is popular nowadays.

Step 4 (research planning). The authors plan to carry out the main tasks, to manage time well, and to scientifically control the progress. 
TABLE 4: Data of 15 DMUs in 2013 (currency unit: 1,000,000 VND).

\begin{tabular}{|c|c|c|c|c|c|c|}
\hline \multirow{2}{*}{ DMUs } & \multicolumn{4}{|c|}{ Inputs } & \multicolumn{2}{|c|}{ Outputs } \\
\hline & (I)TA & (I)CS & (I)SE & (I)AE & $(\mathrm{O}) \mathrm{RS}$ & (O)PT \\
\hline DMU1 & 509991 & 1152459 & 42110 & 54446 & 1306653 & 30880 \\
\hline DMU2 & 657777 & 1062372 & 18633 & 90818 & 1228479 & 57032 \\
\hline DMU3 & 961199 & 962177 & 26726 & 102633 & 1186685 & 14057 \\
\hline DMU4 & 1878363 & 2291270 & 199623 & 192508 & 2818958 & 88070 \\
\hline DMU5 & 158855 & 225771 & 6666 & 9543 & 255462 & 11518 \\
\hline DMU6 & 454291 & 898732 & 18704 & 39094 & 983038 & 29553 \\
\hline DMU7 & 974923 & 2217252 & 70805 & 86102 & 2454787 & 48340 \\
\hline DMU8 & 103426 & 142211 & 1202 & 5371 & 172208 & 21481 \\
\hline DMU9 & 968574 & 1713273 & 38784 & 77527 & 1861925 & 36189 \\
\hline DMU10 & 72358 & 118064 & 18227 & 14084 & 162747 & 6888 \\
\hline DMU11 & 140479 & 398557 & 14232 & 24012 & 459383 & 11949 \\
\hline DMU12 & 1633770 & 1232482 & 46967 & 72444 & 1395956 & 29079 \\
\hline DMU13 & 263782 & 326142 & 10801 & 37282 & 396971 & 9796 \\
\hline DMU14 & 201567 & 178629 & 2769 & 1554 & 196211 & 1127 \\
\hline DMU15 & 2456738 & 4159024 & 226059 & 209707 & 4831173 & 237117 \\
\hline
\end{tabular}

Source: synthetic by researcher [15-29].

TABLE 5: Data of 15 DMUs in 2014 (currency unit: 1,000,000 VND).

\begin{tabular}{|c|c|c|c|c|c|c|}
\hline \multirow{2}{*}{ DMUs } & \multicolumn{4}{|c|}{ Inputs } & \multicolumn{2}{|c|}{ Outputs } \\
\hline & (I)TA & (I)CS & (I)SE & (I)AE & (O)RS & (O)PT \\
\hline DMU1 & 588788 & 1221869 & 46946 & 53530 & 1379742 & 35119 \\
\hline DMU2 & 637070 & 1201404 & 21510 & 115432 & 1409479 & 60497 \\
\hline DMU3 & 1197910 & 1115111 & 27499 & 107228 & 1377234 & 53158 \\
\hline DMU4 & 2127350 & 2454015 & 223486 & 269719 & 3079348 & 92309 \\
\hline DMU5 & 163659 & 257292 & 6585 & 9756 & 292352 & 44954 \\
\hline DMU6 & 581485 & 1137097 & 21124 & 45117 & 1250242 & 40105 \\
\hline DMU7 & 1283842 & 2336302 & 82537 & 79718 & 2593478 & 64483 \\
\hline DMU8 & 112973 & 169561 & 1281 & 6774 & 200017 & 21650 \\
\hline DMU9 & 1144414 & 1042259 & 41498 & 60037 & 1264576 & 89755 \\
\hline DMU10 & 73739 & 133775 & 18326 & 13416 & 176581 & 5879 \\
\hline DMU11 & 230140 & 522542 & 17807 & 27507 & 592539 & 14565 \\
\hline DMU12 & 1573948 & 1394663 & 51566 & 79990 & 1570431 & 46171 \\
\hline DMU13 & 316593 & 412595 & 11231 & 34509 & 490648 & 18879 \\
\hline DMU14 & 5771 & 200702 & 3592 & 2396 & 227138 & 5771 \\
\hline DMU15 & 2908907 & 4749674 & 220757 & 200589 & 5482404 & 296592 \\
\hline
\end{tabular}

Source: synthetic by researcher [15-29].

Step 5 (DMUs collection). The authors collected information of 15 Vietnam textile and apparel companies, which was in line with research objectives through the General Statistics Office's website.

Step 6 (inputs/outputs collection). Input factors include total assets, cost of capital sold, cost of sale, and general and administration expenses.

Output factors include revenue of sales and profit after $\operatorname{tax}$.

Step 7 (grey prediction). The prediction sequence is as follows.
Forecasting. Use business data of 15 DMUs from 2013 to 2016 and apply GM $(1,1)$ to predict business performance from 2017 to 2020 .

Check Accuracy. The authors use mean absolute percentage error (MAPE) to calculate predicted errors, thus ensuring the predicted data are accurate compared with the requirements. In case the accuracy does not meet with the requirements, DMUs must be selected accordingly.

Step 8 (check Pearson coefficient). The authors use the Pearson coefficient to check the correlation between inputs and outputs. Suppose the inputs and outputs have a positive 
TABLE 6: Data of 15 DMUs in 2015 (currency unit: 1,000,000 VND).

\begin{tabular}{|c|c|c|c|c|c|c|}
\hline \multirow{2}{*}{ DMUs } & \multicolumn{4}{|c|}{ Inputs } & \multicolumn{2}{|c|}{ Outputs } \\
\hline & (I)TA & (I)CS & (I)SE & (I)AE & (O)RS & (O)PT \\
\hline DMU1 & 606216 & 1309806 & 51544 & 53208 & 1480821 & 44063 \\
\hline DMU2 & 836542 & 1249641 & 35649 & 136582 & 1502065 & 63458 \\
\hline DMU3 & 1613646 & 1574939 & 36668 & 146519 & 1923940 & 71300 \\
\hline DMU4 & 2735885 & 3538699 & 306195 & 383943 & 4433111 & 115164 \\
\hline DMU5 & 243803 & 232900 & 6489 & 8237 & 262779 & 13084 \\
\hline DMU6 & 458819 & 976675 & 20858 & 47048 & 1083273 & 19945 \\
\hline DMU7 & 1369356 & 2656957 & 107899 & 114281 & 3005032 & 74018 \\
\hline DMU8 & 145849 & 238988 & 1694 & 6378 & 275864 & 29061 \\
\hline DMU9 & 1235441 & 1145009 & 47629 & 62771 & 1349758 & 96707 \\
\hline DMU10 & 73484 & 127695 & 18151 & 13368 & 171465 & 5412 \\
\hline DMU11 & 257599 & 516094 & 26273 & 39332 & 625326 & 26404 \\
\hline DMU12 & 1918836 & 1510140 & 54745 & 79196 & 1756114 & 39766 \\
\hline DMU13 & 487229 & 526497 & 8161 & 47275 & 627916 & 23900 \\
\hline DMU14 & 11659 & 265671 & 2831 & 4351 & 300890 & 11659 \\
\hline DMU15 & 3380138 & 5645821 & 221379 & 237333 & 6408465 & 311044 \\
\hline
\end{tabular}

Source: synthetic by researcher [15-29].

TABLE 7: Data of 15 DMUs in 2016 (currency unit: 1,000,000 VND).

\begin{tabular}{|c|c|c|c|c|c|c|}
\hline \multirow{2}{*}{ DMUs } & \multicolumn{4}{|c|}{ Inputs } & \multicolumn{2}{|c|}{ Outputs } \\
\hline & (I)TA & (I)CS & (I)SE & (I)AE & $(\mathrm{O}) \mathrm{RS}$ & (O)PT \\
\hline DMU1 & 679185 & 1341165 & 52198 & 26851 & 1478313 & 42778 \\
\hline DMU2 & 883468 & 1336254 & 46980 & 148299 & 1611379 & 60986 \\
\hline DMU3 & 1846223 & 1554546 & 28942 & 140127 & 1887749 & 81179 \\
\hline DMU4 & 2707671 & 3412884 & 309616 & 405506 & 4233351 & 52540 \\
\hline DMU5 & 229651 & 212276 & 6716 & 8125 & 248086 & 11748 \\
\hline DMU6 & 533483 & 926722 & 19855 & 48261 & 1013852 & 15293 \\
\hline DMU7 & 1917445 & 2882242 & 90013 & 119504 & 3198584 & 71244 \\
\hline DMU8 & 165293 & 241046 & 1623 & 5724 & 269649 & 22368 \\
\hline DMU9 & 1324281 & 1540328 & 39342 & 84403 & 1738944 & 137131 \\
\hline DMU10 & 88101 & 110327 & 11531 & 13629 & 152988 & 9199 \\
\hline DMU11 & 219244 & 471021 & 29763 & 43920 & 588614 & 31616 \\
\hline DMU12 & 2108020 & 1771020 & 52150 & 90745 & 2000541 & 51154 \\
\hline DMU13 & 718718 & 700224 & 9827 & 46771 & 798022 & 25493 \\
\hline DMU14 & 12562 & 312154 & 3744 & 4664 & 351044 & 12562 \\
\hline DMU15 & 3832596 & 6622654 & 266807 & 259384 & 7526047 & 376606 \\
\hline
\end{tabular}

Source: synthetic by researcher [15-29].

correlation; the result is highly reliable. However, if the correlation coefficient is negative or equals zero, the inputs and outputs must be reselected.

Step 9 (DEA analysis (super-SBM-I-V)). The sequence of DEA analysis according to the super-SBM-I-V model is as follows.

Before Alliance. The actual results of the order and business performance of the DMUs serve as a basis for the authors to choose future alliance partner.

After Alliance. From the preunion assessment, the authors select the DMU target as a partner alliance with other businesses. When combining DMU target with 14 other DMUs, the authors use the SBM-I-V model to analyze and obtain 29 plans to compare and evaluate analysis and comments.

Step 10 (partner selection; conclusion). Based on the results of analysis after the alliance, the authors proposed the most appropriate alliance solution in the supply chain of the enterprises, which brings the highest economic efficiency as well as the affiliate groups that are not highly effective in helping the businesses with suitable direction.

2.4. Grey Forecasting Model. Before using the GM $(1,1)$ model, initial data must be tested against the formula [30]: 


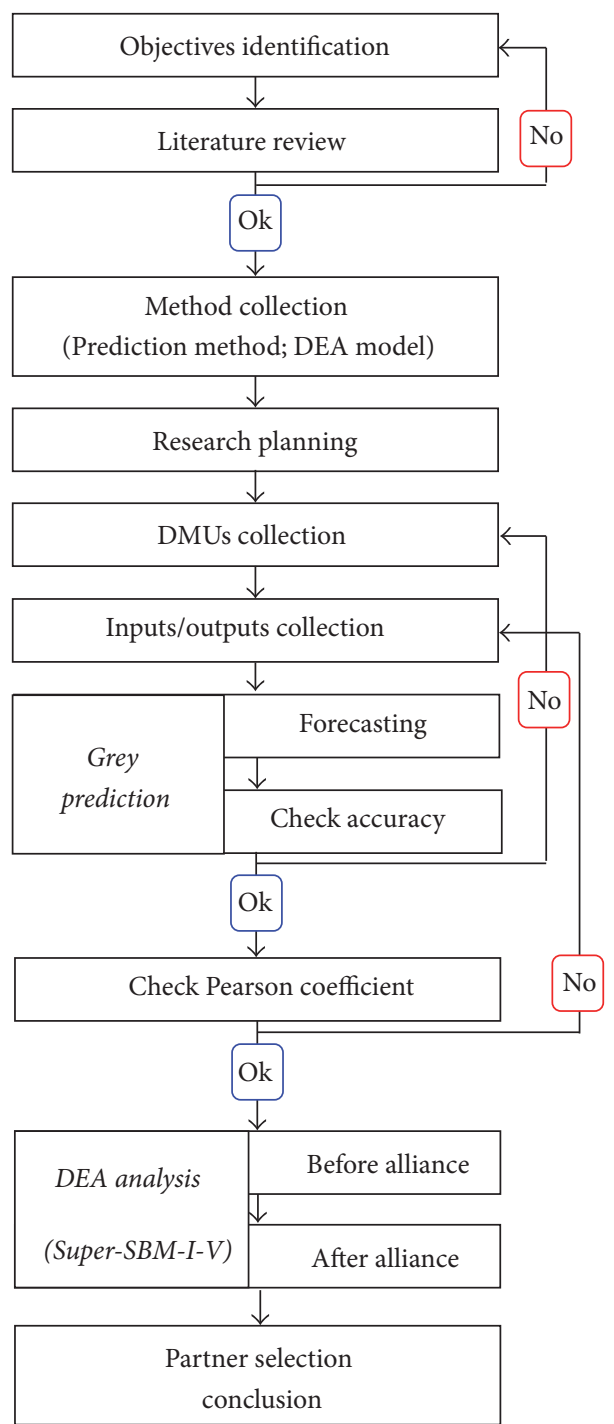

FIGURE 2: Research process.

$$
\delta_{i}=\frac{x^{(0)}(i-1)}{x^{(0)}(i)} ; \quad(i=2,3, \ldots, n)
$$

If all the $\delta_{i}$ values are within $\delta^{(0)}(i)=\left(e^{-2 /(n+1)} ; e^{2 /(n+1)}\right)$, we can use the GM $(1,1)$ model to forecast.

The GM $(1,1)$ model is calculated based on the following differential equation [31]:

$$
\frac{d x^{(1)}(k)}{d k}+a x^{(1)}(k)=b .
$$

Within the equation, $a$ and $b$ are coefficients. The initial data is considered as a value chain as follows:

$$
X^{(0)}=\left(x^{(0)}(1), x^{(0)}(2), \ldots, x^{(0)}(n)\right) ; \quad n \geq 4 .
$$

In this research, $X^{(0)}$ is the actual business metrics of DMUs recorded from 2013 to 2016. Data after being tested will be calculated using the following steps.
Step 1. Calculate the $X^{(1)}$ by using the cumulative method [31]:

$$
\chi^{(1)}=\left(\chi^{(1)}(1), \chi^{(1)}(2), \ldots, \chi^{(1)}(n)\right) ; \quad n \geq 4,
$$

where $\chi^{(1)}(1)=\chi^{(0)}(1), \chi^{(1)}(k)=\sum_{i=1}^{k} \chi^{(0)}(i) ; k=1,2,3, \ldots$, $n$.

Calculate series $Z^{(1)}$ (mean value) of adjacent neighbor $\chi^{(1)}$ by [31]:

$$
Z^{(1)}=\left(Z^{(1)}(1), Z^{(1)}(2), \ldots, Z^{(1)}(n)\right) ; \quad n \geq 4,
$$

where $Z^{(1)}(\kappa)=0.5\left(\chi^{(1)}(\kappa)+\chi^{(1)}(\kappa-1)\right) ; k=2,3, \ldots, n$.

Step 2. Set the equation for the GM $(1,1)$ model and calculate the $Z^{(1)}$ values [31]:

$$
\frac{d X^{(1)}(k)}{d k}+a X^{(1)}(k)=b,
$$

where $Z^{(1)}(\kappa)=0.5\left(x^{(1)}(\kappa)+x^{(1)}(\kappa-1)\right) ; k=2,3, \ldots, n$. 
TABLE 8: The grades of MAPE.

\begin{tabular}{lcccc}
\hline MAPE valuation (\%) & $\leq 10$ & $10 \div 20$ & $20 \div 50$ & $\geq 50$ \\
Accuracy & Excellent & Good & Qualified & Unqualified \\
\hline
\end{tabular}

Sources: [30].

Step 3. Calculate the parameter $a$ and parameter $b$.

Parameter $a$ and parameter $b$ of the GM $(1,1)$ model are calculated based on the least-squares method as follows [31]:

$$
\widehat{a}=\left[\begin{array}{l}
a \\
b
\end{array}\right]^{T}=\left(B^{T} B\right)^{-1} B^{T} \bar{Y}_{N}
$$

where: $B=\left[\begin{array}{cc}-\alpha Z^{(1)}(2) & 1 \\ \vdots & \vdots \\ -\alpha Z^{(1)}(n) & 1\end{array}\right] ; Y_{N}=\left[\begin{array}{c}X^{(0)}(2) \\ \vdots \\ X^{(0)}(n)\end{array}\right]$

Step 4. Set the formula to calculate the predictive value of the model [31]:

$$
\begin{array}{r}
\widehat{X}^{(1)}(\kappa+1)=\left[\chi^{(0)}(1)-\frac{b}{a}\right] e^{-a \kappa}+\frac{b}{a} \\
\quad(\kappa=1,2,3, \ldots) .
\end{array}
$$

Then calculate the predicted values of the GM $(1,1)$ model based on the following formula [31]:

$$
\widehat{X}^{(0)}(k+1)=\widehat{x}^{(1)}(k+1)-\widehat{x}^{(1)}(k),
$$

where $\widehat{x}^{(0)}(1)=x^{(0)}(1) ;(\kappa=1,2,3, \ldots, n)$.

2.5. Evaluation of Volatility Forecasts. In this paper, we use MAPE, which is a tool to measure the accuracy value in statistics, to identify the grey prediction models with good performance. The MAPE is small; It is called the slacks-based measure of efficiency (SBM) [32].

$$
\text { MAPE }=\frac{1}{n}\left[\sum_{i=1}^{n}\left|\frac{A_{i}-F_{i}}{A_{i}}\right| \times 100\right]
$$

The MAPE is divided into our ranks as shown in Table 8.

2.6. Nonradial Super Efficiency Model (Super-SBM). In this section, we propose a model by which we discriminate between such DMUs: it is called the slacks-based measure of efficiency (SBM). Here, a super-SBM is expanded by the addition of the super efficiency to the DEA model with the polarities of the inputs and outputs. The $n$ DMUs with the input/output matrices $(X, Y)$ are used in this model [33], in which $X=\left(x_{i j}\right) \in R^{m \times n}$ and $Y=\left(Y_{i j}\right) \in R^{s \times n} \cdot \lambda$ is a nonnegative vector in $R^{n}$. The vectors $S^{-} \in R^{m}$ and $S^{+} \in R^{S}$ represent an excess input and a short falling output, respectively [34]. The SBM model is given by following equation [35]:

$$
\begin{array}{ll}
\min & \rho=\frac{1-(1 / m) \sum_{i=1}^{m} s_{i}^{-} / x_{i 0}}{1+(1 / s) \sum_{i=1}^{s} s_{i}^{-} / y_{i 0}} \\
\text { s.t: } & \chi_{0}=X \lambda+S^{-} \\
& \gamma_{0}=Y \lambda-S^{+}, \\
& (\lambda \geq 0, X \geq 0, Y \geq 0) .
\end{array}
$$

Suppose $\left(p^{*}, \lambda^{*}, s^{-*}, s^{+*}\right)$ is the optimal condition of SBM, and $\left(\chi_{0}, \gamma_{0}\right)$ is SBM efficient of DMU. When $p^{*}=1$ so $s^{-*}=0$ and $s^{+*}=0$ (or there is no excess input and a short falling output). Hence, a super-efficiency model was introduced for ranking DMUs, and it was defined by the following formula [36]:

$$
\begin{aligned}
& \min \delta=\frac{(1 / m) \sum_{i=1}^{m} \bar{x}_{i} / x_{i 0}}{(1 / s) \sum_{r=1}^{s} \overline{y_{r}} / y_{r 0}} \\
& \text { s.t } \bar{x} \geq \sum_{j=1, \neq 0}^{n} \lambda_{j} x_{j}, \\
& \bar{y} \leq \sum_{j=1, \neq 0}^{n} \lambda_{j} x_{j}, \\
& \bar{\chi} \geq \chi_{0}, \\
& \bar{\gamma} \leq \gamma_{0}, \\
& \bar{\gamma} \geq 0 \\
& \lambda \geq 0 .
\end{aligned}
$$

Suppose the denominator is 1 , so that the objective function is an orientation input of the super-SBM model. The obtained feedback value of the objective function is larger or equivalent to 1 . It is straightforward, then, that the inputs are positive; however, the outputs are able to become a negative value. The proper solution to solve this problem is to use DEA-solver pro 4.1 manual [37], as follows:

Suppose $y_{r o} \leq 0$. It has defined $\bar{\gamma}_{r}^{+}$and $\bar{\gamma}_{-r}^{+}$by

$$
\begin{aligned}
& \bar{y}_{r}^{+}=\max _{j=1, \ldots, n}\left\{y_{r j} \mid y_{r j}>0\right\}, \\
& \bar{y}_{-r}^{+}=\min _{j=1, \ldots, n}\left\{y_{r j} \mid y_{r j}>0\right\} .
\end{aligned}
$$

If there is no positive component in the output $r$, it becomes $\bar{y}_{r}^{+}=y_{-r}^{+}=1$. The element $s_{r}^{+} / \gamma_{r 0}$ is instead the following, while the $\gamma_{r 0}$ is unchanged: 
TABLE 9: Data of DMU1 from 2013 to 2016 (currency unit: 1,000,000 VND).

\begin{tabular}{lcccccc}
\hline Year & & \multicolumn{2}{c}{ Inputs } & & \multicolumn{2}{c}{ Outputs } \\
& $(\mathrm{I}) \mathrm{TA}$ & $(\mathrm{I}) \mathrm{CS}$ & $(\mathrm{I}) \mathrm{SE}$ & $(\mathrm{I}) \mathrm{AE}$ & 54446 & 1306653 \\
2013 & 509991 & 1152459 & 42110 & 53530 & 1379742 \\
2014 & 588788 & 1221869 & 46946 & 53208 & 1480821 \\
2015 & 606216 & 1309806 & 51544 & 26851 & 35119 \\
2016 & 679185 & 1341165 & 52198 & & 44063 \\
\hline
\end{tabular}

Source: synthetic by researcher [9].

When $\bar{\gamma}_{r}^{+}$

$$
>\bar{\gamma}_{-r}^{+} \text {the element is: } \frac{s_{r}^{+}}{\gamma_{-r}^{+}\left(\bar{\gamma}_{r}^{+}-\gamma_{r}^{+}\right) /\left(\bar{\gamma}_{r}^{+}-\gamma_{r 0}\right)}
$$

When $\bar{\gamma}_{r}^{+}$

$$
=\bar{\gamma}_{-r}^{+} \text {the element becomes: } \frac{s_{r}^{+}}{\left(\gamma_{-r}^{+}\right)^{2} / B\left(\bar{\gamma}_{r}^{+}-\gamma_{r 0}\right)} \text {. }
$$

Here, $B$ represents a large positive value; in the DEAsolver the value of $B$ is about 100 .

Given the fact that the denominator is certainly lower than $\gamma_{-r}^{+}$, it increases with the decrease of the distance $\bar{\gamma}_{r}^{+}-\gamma_{r 0}$ and vice versa. Hence, this model significantly affects the nonpositive output value. The obtained score is constant, and it is a unidimensional unit for using units of the measurement [35].

\section{Results}

3.1. Results and Analysis of the Grey Forecasting of the Output Values for All DMUs. The GM (1,1) model is utilized to predict the input and output factors values for each decisionmaking unit from 2017 to 2020. We used factor total assets (TA) - input 1 of DMU1 in Table 9 to explain calculation procedure in this part.

First, we use the GM $(1,1)$ model for trying to forecast the variance of primitive series.

Create the primitive series:

$$
X^{(0)}=(509991 ; 588788 ; 606216 ; 679185) .
$$

Perform the accumulated generating operation (AGO):

$$
\begin{aligned}
X^{(1)} & =(509991 ; 1098779 ; 1704995 ; 2384180) \\
x^{(1)}(1) & =x^{(0)}(1)=509991 \\
x^{(1)}(2) & =x^{(0)}(1)+x^{(0)}(2)=1098779 \\
x^{(1)}(3) & =x^{(1)}(2)+x^{(0)}(3)=1704995 \\
x^{(1)}(4) & =x^{(1)}(3)+x^{(0)}(4)=2384180 .
\end{aligned}
$$

Create the different equation of GM $(1,1)$.
To find $X^{(1)}$ series, the following mean obtained by the mean equation is

$$
\begin{aligned}
& z^{(1)}(2)=0.5 \times(509991+1098779)=804385 \\
& z^{(1)}(3)=0.5 \times(1098779+1704995)=1401887 \\
& z^{(1)}(4)=0.5 \times(1704995+2384180)=2044587.5 .
\end{aligned}
$$

Solve equations.

To find $a$ and $b$, the primitive series values are substituted into the grey differential equation to obtain

$$
\begin{array}{r}
588788+a \times 804385=b \\
606216+a \times 1401887=b \\
679185+a \times 2044587.5=b .
\end{array}
$$

Convert the linear equations into the form of a matrix.

Let

$$
\begin{aligned}
& B=\left[\begin{array}{cc}
-804385 & 1 \\
-1401887 & 1 \\
-2044587.5 & 1
\end{array}\right] ; \\
& \widehat{\theta}=\left[\begin{array}{l}
a \\
b
\end{array}\right] ;
\end{aligned}
$$

$$
Y_{N}=\left[\begin{array}{l}
588788 \\
606216 \\
679185
\end{array}\right] \text {. }
$$

And then use the least-squares method to find $a$ and $b$ :

$$
\left[\begin{array}{l}
a \\
b
\end{array}\right]=\widehat{\theta}=\left(B^{T} B\right)^{-1} B^{T} y_{N}=\left[\begin{array}{c}
-0.0734 \\
520724.6709
\end{array}\right] \text {. }
$$

Use the two coefficients $a$ and $b$ to generate the whitening equation of the differential equation:

$$
\frac{d x^{(1)}}{d k}+0.0734 \times x^{(1)}=520724.6709
$$


TABLE 10: Data of 15 DMUs in 2017 (currency unit: 1,000,000 VND).

\begin{tabular}{|c|c|c|c|c|c|c|}
\hline \multirow{2}{*}{ DMUs } & \multicolumn{4}{|c|}{ Inputs } & \multicolumn{2}{|c|}{ Outputs } \\
\hline & (I)TA & (I)CS & (I)SE & (I)AE & (O)RS & (O)PT \\
\hline DMU1 & 721814.76 & 1413714.89 & 55627.68 & 25296.03 & 1546318.61 & 48544.08 \\
\hline DMU2 & 1053997.39 & 1403749.17 & 67264.71 & 169108.78 & 1720725.30 & 62130.40 \\
\hline DMU3 & 2294455.62 & 1881264.48 & 32380.04 & 165411.22 & 2268702.20 & 100498.51 \\
\hline DMU4 & 3130664.07 & 4143249.39 & 371956.57 & 502950.15 & 5121472.13 & 57986.82 \\
\hline DMU5 & 281200.84 & 192406.24 & 6729.79 & 7154.80 & 225963.51 & 3242.28 \\
\hline DMU6 & 475353.42 & 816765.35 & 19381.36 & 50028.24 & 895875.88 & 7694.20 \\
\hline DMU7 & 2302526.94 & 3212821.85 & 100626.19 & 148225.35 & 3579094.18 & 76730.92 \\
\hline DMU8 & 200487.46 & 293300.49 & 1885.72 & 5316.81 & 321723.30 & 25020.34 \\
\hline DMU9 & 1424974.01 & 1844619.97 & 40822.27 & 98235.86 & 2007490.91 & 166631.40 \\
\hline DMU10 & 94367.97 & 102522.46 & 10619.72 & 13686.16 & 145006.42 & 11240.91 \\
\hline DMU11 & 225439.67 & 454380.31 & 38423.52 & 55629.26 & 598318.91 & 45151.67 \\
\hline DMU12 & 2453736.30 & 1978048.44 & 53396.32 & 94910.26 & 2250200.03 & 51258.86 \\
\hline DMU13 & 1046331.33 & 901189.93 & 8305.48 & 55816.79 & 1008742.38 & 29953.18 \\
\hline DMU14 & 17985.77 & 388587.67 & 3557.42 & 6423.83 & 435973.52 & 17985.77 \\
\hline DMU15 & 4397864.35 & 7798797.34 & 287608.15 & 296483.83 & 8786351.84 & 418309.95 \\
\hline
\end{tabular}

Sources: calculated by researcher.

Find the prediction model from equation

$$
\begin{aligned}
\widehat{X}^{(1)}(\kappa+1)= & {\left[\chi^{(0)}(1)-\frac{b}{a}\right] \times e^{-a \kappa}+\frac{b}{a} } \\
= & {\left[509991-\frac{520724.6709}{(-0.0734)}\right] } \\
& \times e^{-(-0.0734) \kappa}+\frac{520724.6709}{(-0.0734)} \\
= & 7604289.363 \times e^{0.0734 \times k} \\
& -7094298.363 .
\end{aligned}
$$

Substitute different value of $k$ into the equation

$$
\begin{array}{ll}
X^{(1)}(1)=509991 \quad k=0 ; \\
X^{(1)}(2)=1089144.30 & k=1 ; \\
X^{(1)}(3)=1712406.71 & k=2 ; \\
X^{(1)}(4)=2383137.67 & k=3 ; \\
X^{(1)}(5)=3104952.43 & k=4 ; \\
X^{(1)}(6)=3881741.61 & k=5 ; \\
X^{(1)}(7)=4717692.14 & k=6 ; \\
X^{(1)}(8)=5617309.83 & k=7 ;
\end{array}
$$

derive the predicted value of the original series according to the accumulated generating operation and obtain

$$
\begin{aligned}
& \widehat{x}^{(0)}(1)=x^{(1)}(1)=509991 \\
& \widehat{x}^{(0)}(2)=\widehat{x}^{(1)}(2)-\widehat{x}^{(1)}(1)=579153.30
\end{aligned}
$$

$$
\begin{aligned}
\hat{x}^{(0)}(3) & =\widehat{x}^{(1)}(3)-\widehat{x}^{(1)}(2)=623262.42 \\
\hat{x}^{(0)}(4) & =\widehat{x}^{(1)}(4)-\widehat{x}^{(1)}(3)=670730.95 \\
\hat{x}^{(0)}(5) & =\widehat{x}^{(1)}(5)-\widehat{x}^{(1)}(4) \\
& =721814.76 \text { - Result forecast of } 2017 .
\end{aligned}
$$$$
\widehat{x}^{(0)}(6)=\widehat{x}^{(1)}(6)-\widehat{x}^{(1)}(5)
$$$$
=776789.18-\text { Result forecast of } 2018 .
$$$$
\widehat{x}^{(0)}(7)=\widehat{x}^{(1)}(7)-\widehat{x}^{(1)}(6)
$$$$
=835950.53-\text { Result forecast of } 2019 .
$$

$$
\begin{aligned}
\widehat{x}^{(0)}(8) & =\widehat{x}^{(1)}(8)-\widehat{x}^{(1)}(7) \\
& =899617.69-\text { Result forecast of } 2020 .
\end{aligned}
$$

As with above process, we have the result of all DMUs from 2017 to 2020, respectively, in Tables 10, 11, 12, and 13.

In this study, the authors use MAPE to check the accuracy of forecasts to ensure appropriate predictive methods and as a basis for highly reliable assessments. The results are shown in Table 14.

This research uses a model-based forecasting approach (an approach to obtain information for the future with modeling tools); through resimulating the past and comparing values, the forecast is calculated by actual data and the model; if the error is within the allowable limits, then the model is reliable and usable. As shown in Table 14, average MAPE of 15 DMUs is less than $10 \%$. Based on rules, as shown in Table 8 , the predicted results in this study have a high level of accuracy (average MAPE of 15 DMUs is 
TABLE 11: Data of 15 DMUs in 2018 (currency unit: 1,000,000 VND).

\begin{tabular}{|c|c|c|c|c|c|c|}
\hline \multirow{2}{*}{ DMUs } & \multicolumn{4}{|c|}{ Inputs } & \multicolumn{2}{|c|}{ Outputs } \\
\hline & (I)TA & (I)CS & (I)SE & (I)AE & (O)RS & (O)PT \\
\hline DMU1 & 776789.18 & 1480059.07 & 58572.89 & 19300.11 & 1599270.79 & 53131.91 \\
\hline DMU2 & 1226468.27 & 1481143.18 & 96220.54 & 190968.19 & 1840070.14 & 62373.71 \\
\hline DMU3 & 2813720.28 & 2178272.62 & 33076.22 & 186161.97 & 2608027.98 & 122708.61 \\
\hline DMU4 & 3495299.88 & 4781494.65 & 430700.05 & 604322.45 & 5878474.45 & 47705.47 \\
\hline DMU5 & 324822.64 & 174740.33 & 6797.49 & 6498.75 & 207884.79 & 1380.11 \\
\hline DMU6 & 452735.10 & 734911.71 & 18797.32 & 51732.30 & 804655.10 & 4497.72 \\
\hline DMU7 & 2863522.13 & 3562321.21 & 104426.16 & 177677.19 & 3962721.45 & 80419.71 \\
\hline DMU8 & 240420.59 & 342986.29 & 2096.21 & 4894.19 & 367301.15 & 25358.17 \\
\hline DMU9 & 1532556.94 & 2270676.18 & 39861.49 & 118106.13 & 2376926.55 & 209816.16 \\
\hline DMU10 & 103714.56 & 93407.36 & 8711.68 & 13795.21 & 135247.46 & 14709.18 \\
\hline DMU11 & 220517.09 & 431990.09 & 48542.73 & 68926.94 & 596408.96 & 63025.78 \\
\hline DMU12 & 2824812.20 & 2235788.48 & 53686.99 & 101400.69 & 2541235.71 & 54332.00 \\
\hline DMU13 & 1559205.34 & 1176387.15 & 7680.31 & 63932.10 & 1284240.82 & 34505.81 \\
\hline DMU14 & 24530.38 & 480066.86 & 3645.25 & 8464.64 & 536697.39 & 24530.38 \\
\hline DMU15 & 5041317.17 & 9198794.29 & 318016.79 & 335956.54 & 10293643.64 & 474013.17 \\
\hline
\end{tabular}

Sources: calculated by researcher.

TABLE 12: Data of 15 DMUs in 2019 (currency unit: 1,000,000 VND).

\begin{tabular}{|c|c|c|c|c|c|c|}
\hline \multirow{2}{*}{ DMUs } & \multicolumn{4}{|c|}{ Inputs } & \multicolumn{2}{|c|}{ Outputs } \\
\hline & (I)TA & (I)CS & (I)SE & (I)AE & (O)RS & (O)PT \\
\hline DMU1 & 835950.53 & 1549516.73 & 61674.04 & 14725.40 & 1654036.27 & 58153.32 \\
\hline DMU2 & 1427161.42 & 1562804.22 & 137641.17 & 215653.21 & 1967692.42 & 62617.97 \\
\hline DMU3 & 3450501.19 & 2522171.46 & 33787.36 & 209515.89 & 2998106.11 & 149827.14 \\
\hline DMU4 & 3902405.69 & 5518058.16 & 498720.94 & 726126.87 & 6747368.91 & 39247.05 \\
\hline DMU5 & 375211.34 & 158696.43 & 6865.88 & 5902.85 & 191252.51 & 587.46 \\
\hline DMU6 & 431193.01 & 661261.18 & 18230.88 & 53494.41 & 722722.69 & 2629.18 \\
\hline DMU7 & 3561200.02 & 3949840.06 & 108369.64 & 212981.01 & 4387468.04 & 84285.84 \\
\hline DMU8 & 288307.62 & 401088.98 & 2330.18 & 4505.17 & 419335.92 & 25700.56 \\
\hline DMU9 & 1648262.18 & 2795139.59 & 38923.33 & 141995.57 & 2814348.88 & 264192.82 \\
\hline DMU10 & 113986.88 & 85102.67 & 7146.46 & 13905.12 & 126145.28 & 19247.55 \\
\hline DMU11 & 215701.99 & 410703.18 & 61326.93 & 85403.31 & 594505.11 & 87975.68 \\
\hline DMU12 & 3252005.51 & 2527112.08 & 53979.24 & 108334.98 & 2869913.27 & 57589.39 \\
\hline DMU13 & 2323471.75 & 1535621.61 & 7102.19 & 73227.30 & 1634980.85 & 39750.40 \\
\hline DMU14 & 33456.42 & 593081.58 & 3735.26 & 11153.81 & 660691.70 & 33456.42 \\
\hline DMU15 & 5778913.76 & 10850110.93 & 351640.51 & 380684.49 & 12059510.17 & 537133.97 \\
\hline
\end{tabular}

Sources: calculated by researcher.

4.08\%). This confirms that the GM $(1,1)$ model used in this study is suitable with highly reliable predicted results and analysis.

3.2. Pearson Correlation. In this study, the authors use the super-SBM-I-V model to analyze and choose a strategic alliance partner for DMUs, where the condition for using DEA is the correlation coefficient, which could not be negative or equal to 0 . Hence, before analyzing DEA, the authors used the Pearson correlation coefficient to determine the data used in this study, which is in accordance with the DEA standards. Correlation coefficients are always in the range of $(-1)$ to (1); if this factor is as close to (1), it is a perfect linear relation [37]. The results are shown in Tables 15, 16, 17, and 18.

Results of the Pearson correlation coefficient from Tables 15 to 18 show that the factors used in this study have a strong linear relationship, which is consistent with the conditions of DEA and can be used for analysis. In the super-SBM-I$\mathrm{V}$ model, strategic partners will be selected for DMUs in the future.

\subsection{Analysis Alliance}

3.3.1. Analysis before Alliance. To identify and select the target DMU for alliance with other DMUs in the future, the authors 
TABLE 13: Data of 15 DMUs in 2020 (currency unit: 1,000,000 VND).

\begin{tabular}{|c|c|c|c|c|c|c|}
\hline \multirow{2}{*}{ DMUs } & \multicolumn{4}{|c|}{ Inputs } & \multicolumn{2}{|c|}{ Outputs } \\
\hline & (I)TA & (I)CS & (I)SE & (I)AE & (O)RS & (O)PT \\
\hline DMU1 & 899617.69 & 1622233.95 & 64939.38 & 11235.04 & 1710677.14 & 63649.31 \\
\hline DMU2 & 1660695.01 & 1648967.54 & 196892.37 & 243529.08 & 2104166.24 & 62863.20 \\
\hline DMU3 & 4231393.77 & 2920363.98 & 34513.79 & 235799.54 & 3446527.55 & 182938.84 \\
\hline DMU4 & 4356928.06 & 6368085.31 & 577484.45 & 872481.62 & 7744694.24 & 32288.35 \\
\hline DMU5 & 433416.69 & 144125.61 & 6934.96 & 5361.60 & 175950.92 & 250.06 \\
\hline DMU6 & 410675.94 & 594991.68 & 17681.50 & 55316.53 & 649132.88 & 1536.91 \\
\hline DMU7 & 4428862.42 & 4379514.24 & 112462.04 & 255299.58 & 4857741.34 & 88337.82 \\
\hline DMU8 & 345732.79 & 469034.41 & 2590.28 & 4147.07 & 478742.33 & 26047.57 \\
\hline DMU9 & 1772702.95 & 3440739.56 & 38007.25 & 170717.17 & 3332269.41 & 332661.92 \\
\hline DMU10 & 125276.61 & 77536.33 & 5862.46 & 14015.91 & 117655.67 & 25186.19 \\
\hline DMU11 & 210992.04 & 390465.21 & 77477.97 & 105818.21 & 592607.33 & 122802.45 \\
\hline DMU12 & 3743802.81 & 2856395.20 & 54273.08 & 115743.46 & 3241101.23 & 61042.07 \\
\hline DMU13 & 3462354.10 & 2004555.83 & 6567.59 & 83873.95 & 2081511.77 & 45792.13 \\
\hline DMU14 & 45630.44 & 732701.61 & 3827.48 & 14697.32 & 813332.68 & 45630.44 \\
\hline DMU15 & 6624428.33 & 12797862.80 & 388819.25 & 431367.35 & 14128309.73 & 608660.09 \\
\hline
\end{tabular}

Sources: calculated by researcher.

TABLE 14: Average MAPE of 15 DMUs.

\begin{tabular}{lc}
\hline DMUs & Average MAPE (\%) \\
\hline DMU1 & 3.51 \\
DMU2 & 1.79 \\
DMU3 & 5.36 \\
DMU4 & 7.72 \\
DMU5 & 5.29 \\
DMU6 & 3.01 \\
DMU7 & 3.78 \\
DMU8 & 4.85 \\
DMU9 & 3.59 \\
DMU10 & 4.13 \\
DMU11 & 3.90 \\
DMU12 & 2.40 \\
DMU13 & 3.28 \\
DMU14 & 7.38 \\
DMU15 & 1.27 \\
Average MAPE of 15 DMUs & $4.08(\%)$ \\
\hline
\end{tabular}

Source: calculated by researcher.

use actual business data of the DMUs and the analytical applications from the super SBM-I-V of DEA to evaluate the business situation of DMUs before the alliance. The results are shown in Table 19.

3.3.2. Analysis after Alliance. Based on the actual performance of the business in 2016 and the results of business analysis obtained from the super-SBM-I-V software, the authors establishe DMU5 as the alliance target for the business. If we choose low-rated and performance DMUs, it will be difficult to persuade other DMUs to join the alliance. When combing DMU5 to other 14 DMUs, the authors have 29 combinations. The authors used software of a DEA-solver pro 8.0-super-SBM-I-V model and obtained the results, as shown in Table 20.

In this study, DMU5 was chosen as the target DMU for alliances with other enterprises in the textile supply chain because DMU5's business performance in 2016 was ineffective (specifically DMU5 $5_{\text {Rank }}=14$ (14/15 DMUs); DMU5 $5_{\text {Score }}=$ $0.9998)$. Hence, the DMU5 management team needs to boldly change the strategy and choose an alliance solution with other DMUs to improve their business efficiency. On the other hand, DMU5 (Ha Dong Textile J.S.C), established in 1956, has a long history in the textile industry, with a large market and modern technology, and can easily persuade other DMUs to join their alliance.

Based on the ranking and efficiency score at Table 20, we can separate into two groups good alliances cooperative and inappropriate alliances as follows.

Group 1. After strategic alliances, the DMUs get good business efficiency, make the relationship among the coalition parties better, and expand market share. Candidates need to own good characteristics and necessary consistency with one's desire in business. There are 13 DMUs (DMU14, DMU8, DMU9, DMU3, DMU1, DMU13, DMU7, DMU10, DMU6, DMU11, DMU4, DMU2, DMU15) in this group, which help DMU5 to improve results after the strategic alliance. Alliances DMU5 + DMU14, DMU5 + DMU8, DMU5 + DMU9, DMU5 + DMU3, DMU5 + DMU1, DMU5 + DMU13, DMU5 + DMU7, DMU5 + DMU10, DMU5 + DMU6, DMU5 + DMU11, DMU5 + DMU4, DMU5 + DMU2, DMU5 + DMU15 receive a score of more than 1 . These are shown in Table 21.

Group 2. In this group, DMU12 combined with DMU5 shows no any progress after alliance. Thus, this combined will not be priority with selection of a strategic alliance partner in the future, as shown in Table 22. 
TABLE 15: Correlation of inputs and outputs in 2013.

\begin{tabular}{lcccccc}
\hline & TA & CS & SE & AE & RS \\
\hline TA & 1.0000 & 0.9077 & 0.8869 & 0.9286 & 0.9176 & 0.9985 \\
CS & 0.9077 & 1.0000 & 0.8977 & 0.9064 & 0.9218 & 0.9168 \\
SE & 0.8869 & 0.8977 & 1.0000 & 1.0000 & 0.9245 & 0.9108 \\
AE & 0.9286 & 0.9064 & 0.9218 & 0.9245 & 0.8809 \\
RS & 0.9176 & 0.9985 & 0.9168 & 0.8329 & 0.8329 \\
PT & 0.8134 & 0.9108 & 0.8809 & 0.9175 & 0.9175 \\
\hline
\end{tabular}

Source: calculated by researcher.

TABLE 16: Correlation of inputs and outputs in 2014.

\begin{tabular}{lccccrc}
\hline & TA & CS & SE & AE & RS \\
TA & 1.0000 & 0.9322 & 0.8973 & 0.8745 & 0.9429 & 0.9984 \\
CS & 0.9322 & 1.0000 & 0.8894 & 0.8028 & 0.9104 & 0.9086 \\
SE & 0.8973 & 0.8894 & 0.0000 & 1.0000 & 0.8316 & 0.9176 \\
AE & 0.8745 & 0.8028 & 0.9104 & 0.8316 & 0.7912 \\
RS & 0.9429 & 0.9984 & 0.9086 & 0.6814 & 0.6814 \\
PT & 0.8528 & 0.9176 & & 0.9181 & 0.9181 \\
\hline
\end{tabular}

Source: calculated by researcher.

TABLE 17: Correlation of inputs and outputs in 2015.

\begin{tabular}{|c|c|c|c|c|c|c|}
\hline & $\mathrm{TA}$ & CS & SE & $\mathrm{AE}$ & RS & $\mathrm{PT}$ \\
\hline$\overline{\mathrm{TA}}$ & 1.0000 & 0.9328 & 0.8608 & 0.8601 & 0.9425 & 0.8548 \\
\hline CS & 0.9328 & 1.0000 & 0.8774 & 0.8203 & 0.9983 & 0.9284 \\
\hline SE & 0.8608 & 0.8774 & 1.0000 & 0.9376 & 0.8999 & 0.7319 \\
\hline $\mathrm{AE}$ & 0.8601 & 0.8203 & 0.9376 & 1.0000 & 0.8517 & 0.6716 \\
\hline RS & 0.9425 & 0.9983 & 0.8999 & 0.8517 & 1.0000 & 0.9185 \\
\hline $\mathrm{PT}$ & 0.8548 & 0.9284 & 0.7319 & 0.6716 & 0.9185 & 1.0000 \\
\hline
\end{tabular}

Source: calculated by researcher.

TABLE 18: Correlation of inputs and outputs in 2016.

\begin{tabular}{lcccccc}
\hline & TA & CS & SE & AE & RS \\
\hline TA & 1.0000 & 0.9404 & 0.8370 & 0.8303 & 0.9463 & 0.7818 \\
CS & 0.9404 & 1.0000 & 0.8667 & 0.7728 & 0.9300 & 0.8873 \\
SE & 0.8370 & 0.8667 & 1.0000 & 1.0000 & 0.8031 & 0.8835 \\
AE & 0.8303 & 0.7728 & 0.9300 & 0.8031 & 1.0000 & 0.6227 \\
RS & 0.9463 & 0.9987 & 0.8873 & 0.5075 & 0.8714 \\
PT & 0.7818 & 0.8835 & 0.6227 & & 0.8714 \\
\hline
\end{tabular}

Source: calculated by researcher.

3.4. Discussion of Alliance Partner Selection. DMUs include DMU14, DMU8, DMU9, DMU3, DMU1, DMU13, DMU7, DMU10, DMU6, DMU11, DMU4, DMU2, and DMU15. But these DMUs would not be willing to combine with DMU5 because some companies have a score after an alliance, and ranking is reduced before an alliance.

In alliances that bring high performance in group 1, DMU9 (Saigon 3 garment joint stock company, GATEXIM), before alliance, has a ranking at 3 (3/15 DMUs); however, after the alliance, its ranking is at 8 (8/29 DMUs). Hence, the effect given is immensely good; specifically, DMU5 in Hanam (the large economic center in the northern region of Vietnam) specializes in the textile industry and the DMU9 in Ho Chi Minh City (the largest economic center in the south of Vietnam) specializes in the garment industry. Thus, in terms of expertise, these two companies joined the alliance between textile and apparel enterprises when the parties signed the main agreement, which helps to build the supply chain by eliminating intermediaries between suppliers and consumers and shorten the length of the channel consumption. Joining 
TABLE 19: Rank and score before alliances.

\begin{tabular}{lcc}
\hline Rank & DMU & Score \\
\hline 1 & DMU14 & 4.9495 \\
2 & DMU8 & 2.1602 \\
3 & DMU9 & 1.4468 \\
4 & DMU10 & 1.3776 \\
5 & DMU1 & 1.1660 \\
6 & DMU3 & 1.1542 \\
7 & DMU7 & 1.0303 \\
8 & DMU11 & 1.0262 \\
9 & DMU13 & 1.0251 \\
10 & DMU6 & 1.0241 \\
11 & DMU4 & 1.0183 \\
12 & DMU2 & 1.0105 \\
13 & DMU15 & 1.0000 \\
14 & DMU5 & 0.9998 \\
15 & DMU12 & 0.8677 \\
\hline
\end{tabular}

Source: calculated by researcher.

TABLE 20: Performance ranking of virtual DMUs.

\begin{tabular}{|c|c|c|}
\hline Rank & DMU & Score \\
\hline 1 & DMU14 & 4.5722 \\
\hline 2 & DMU8 & 1.9574 \\
\hline 3 & DMU10 & 1.3776 \\
\hline 4 & DMU5 + DMU14 & 1.0526 \\
\hline 5 & DMU1 & 1.0498 \\
\hline 6 & DMU9 & 1.0473 \\
\hline 7 & DMU5 + DMU8 & 1.0293 \\
\hline 8 & DMU5 + DMU9 & 1.0292 \\
\hline 9 & DMU5 + DMU3 & 1.0266 \\
\hline 10 & DMU11 & 1.0254 \\
\hline 11 & DMU13 & 1.0251 \\
\hline 12 & DMU3 & 1.0193 \\
\hline 13 & DMU5 + DMU1 & 1.0189 \\
\hline 14 & DMU6 & 1.0170 \\
\hline 15 & DMU5 + DMU13 & 1.0092 \\
\hline 16 & DMU5 + DMU7 & 1.0084 \\
\hline 17 & DMU15 & 1.0067 \\
\hline 18 & DMU2 & 1.0043 \\
\hline 19 & DMU7 & 1.0042 \\
\hline 20 & DMU5 + DMU10 & 1.0040 \\
\hline 21 & DMU5 + DMU6 & 1.0032 \\
\hline 22 & DMU4 & 1.0026 \\
\hline 23 & DMU5 + DMU11 & 1.0024 \\
\hline 24 & DMU5 + DMU4 & 1.0019 \\
\hline 25 & DMU5 + DMU2 & 1.0006 \\
\hline 26 & DMU5 + DMU15 & 1.0000 \\
\hline 27 & DMU5 & 0.9998 \\
\hline 28 & DMU5 + DMU12 & 0.8802 \\
\hline 29 & DMU12 & 0.8533 \\
\hline
\end{tabular}

Source: calculated by researcher. the alliance helps businesses ensure that the factors of supply and consumption remain stable. In terms of geographic location, enterprises can deploy and expand their distribution network so that they can take advantage of the available network and human resources of their partners. This not only helps to save cost but also reduces time entering a market to the fullest. Besides, joining alliances also can increase the customer base by leveraging each other's customer systems. Because every business has its own characteristics matching its inherent potential, alliances will have their own advantages to exploit and complement each other. Hence, in order to survive, compete, and develop, an alliance is inevitably a trend because it gives firms greater value-added alliance than standing alone. Hence, in order to survive, compete, and develop, an alliance is inevitably a trend because it gives firms greater value-added alliance than standing alone, to gain greater economic benefits on a larger scale, to increase prestige and brand name, to reduce costs, to maximize business advantages of parties involved, and to develop the customer base and distribution network. This will help strengthen the position and competitiveness in the market and improve business efficiency.

\section{Conclusions}

With what has been happening in the textile and apparel industry, the need for linking is becoming increasingly urgent. In this study, the authors provide a method for finding and selecting the right strategic partner for textile and apparel enterprises. The selected plan is to promote the internal strength of all participating enterprises while promoting the strength of the alliance in accordance with high volume products, high quality, international quality, timely delivery, and competitive price needs. Authorities can rely on these research results to make the correct and appropriate strategic decisions in helping Vietnam's textile and apparel industry to develop when integrating with the global economy.

Although the paper shows that GM $(1,1)$ is a flexible and easy model of use to predict what would happen in the future business and DEA is an efficient tool to help businesses find the right strategic partner, we still cannot deny some restrictions about these two methods for further studies. Different DEA models and optimization algorithm can also be tested to reveal more changes, and other industries can be studied by this model in the future [38]. This study only focuses on a quantitative model. The authors will do more research of external environmental factors in the future. The comparisons with other quantitative and qualitative approaches will be a good research direction as well.

\section{Conflicts of Interest}

The authors declare no conflicts of interest.

\section{Acknowledgments}

This research was supported in part by MOST 105-2221-E151-039 from the Ministry of Sciences and Technology. The 
TABLE 21: The good alliances.

\begin{tabular}{lccc}
\hline $\begin{array}{l}\text { Virtual } \\
\text { Alliance }\end{array}$ & $\begin{array}{c}\text { Target DMU5 } \\
\text { Ranking (a) }\end{array}$ & $\begin{array}{c}\text { Virtual alliance } \\
\text { Ranking (b) }\end{array}$ & $\begin{array}{c}\text { Difference } \\
(\mathrm{a})-(\mathrm{b})\end{array}$ \\
\hline DMU5 + DMU14 & 27 & 4 & 23 \\
DMU5 + DMU8 & 27 & 8 & 20 \\
DMU5 + DMU9 & 27 & 9 & 19 \\
DMU5 + DMU3 & 27 & 13 & 18 \\
DMU5 + DMU1 & 27 & 15 & 14 \\
DMU5 + DMU13 & 27 & 16 & 12 \\
DMU5 + DMU7 & 27 & 20 & 7 \\
DMU5 + DMU10 & 27 & 21 & \\
DMU5 + DMU6 & 27 & 23 & \\
DMU5 + DMU11 & 27 & 24 & 3 \\
DMU5 + DMU4 & 27 & 25 & 2 \\
DMU5 + DMU2 & 27 & 26 & 1 \\
DMU5 + DMU15 & 27 & & \\
\hline
\end{tabular}

Source: calculated by researcher.

TABLE 22: The inappropriate alliance.

\begin{tabular}{lccc}
\hline $\begin{array}{l}\text { Virtual } \\
\text { Alliance }\end{array}$ & $\begin{array}{c}\text { Target DMU5 } \\
\text { Ranking (a) }\end{array}$ & $\begin{array}{c}\text { Virtual alliance } \\
\text { Ranking (b) }\end{array}$ & $\begin{array}{c}\text { Difference } \\
(\mathrm{a})-(\mathrm{b})\end{array}$ \\
\hline DMU5 + DMU12 & 27 & 28 & $(-1)$ \\
\hline
\end{tabular}

Source: calculated by researcher.

authors also appreciate the support from Fortune Institute of Technology and National Kaohsiung University of Applied Sciences in Taiwan.

\section{References}

[1] Taichinh, Textile and apparel stocks crowned, http://tapchitaichinh.vn.

[2] Virac JSC, Markets of Vietnam's Textile and Apparel, http:// viracresearch.com.

[3] G. Gereffi, "The international competitiveness of Asian economies in the apparel commodity chain," ERD Working Paper Series, no. 5, pp. 1-34, 2002.

[4] J. Deng, "Control problems of grey systems," Systems and Control Letters, vol. 1, no. 5, pp. 288-294, 1982.

[5] D. Bunn, "Forecasting with more than one model," Journal of Forecasting, vol. 8, no. 3, pp. 161-166, 1989.

[6] G. Chen, K. Li, T. Chung, H. Sun, and G. Tang, "Application of an innovative combined forecasting method in power system load forecasting," Electric Power Systems Research, vol. 59, no. 2, pp. 131-137, 2001.

[7] D. Yamaguchi, G. D. Li, and M. Nagai, "Grey relational analysis for finding the invariable structure and its applications," The Journal of Grey System, vol. 8, no. 2, pp. 167-178, 2005.

[8] Y. Lingbin, Z. Xia, and W. Jin, "Prediction of the number of international tourists in China based on gray model $(1,1)$," in Proceedings of the 2009 International Conference on Electronic Commerce and Business Intelligence (ECBI '09), pp. 357-360, Beijing, China, June 2009.

[9] G. Büyüközkan, O. Feyzioğlu, and E. Nebol, "Selection of the strategic alliance partner in logistics value chain," International
Journal of Production Economics, vol. 113, no. 1, pp. 148-158, 2008.

[10] E. Y. Candace and A. T. Thomas, "Strategic alliances with competing firms and shareholder value," Journal of Management and Marketing Research, vol. 6, pp. 1-10, 2011.

[11] C. N. Wang, N. T. Nguyen, T. T. Tran, and B. B. Huong, "A study of the strategic alliance for EMS industry: the application of a hybrid DEA and GM $(1,1)$ approach," The Scientific World Journal, vol. 2015, Article ID 948793, 2015.

[12] C.-N. Wang, X.-T. Nguyen, and Y.-H. Wang, "Automobile industry strategic alliance partner selection: The application of a hybrid dea and grey theory model," Sustainability, vol. 8, no. 2, article no. 173, 2016.

[13] C.-N. Wang and H.-K. Nguyen, "Enhancing urban development quality based on the results of appraising efficient performance of investors-a case study in vietnam," Sustainability, vol. 9, no. 8, p. 1397, 2017.

[14] B. A. Hung, Overview of export activities Vietnam's Textile and Apparel in 2016, http://cafef.vn.

[15] Hue Textile Garment Joint Stock Company, Financial report. http://huegatex.com.vn.

[16] SaiGon Garment Manufacturing Trade J.S.C, Financial report. http://www.garmexsaigon-gmc.com.

[17] TNG Investment and Trading Joint Stock Company, Financial report. http://www.tng.vn.

[18] Nha Be Garment Corporation Joint Stock company, Financial report. https://www.nhabe.com.vn.

[19] Ha Dong textile joint stock company, Financial report. http://dethadong.vn/.

[20] DongNai Garment Corporation, Financial report. http://www .donagamex.com.vn. 
[21] HoaTho Textile Garment Joint Stock company, Financial report. http://www.hoatho.com.vn.

[22] Phan Thiet Garment Import Export J.S.C, Financial report. http://www.phanthietgarment.com.vn.

[23] Saigon 3 Garment Joint Stock Company, Financial report. http://www.saigon3.com.vn.

[24] ThangLoi International Garment J.S.C, Financial report. http://www.maythangloi.com.vn.

[25] HaNoi Industrial Textile Joint Stock Company, Financial report. http://haicatex.com.

[26] HaNoi Textile and Garment Joint Stock Corporation, Financial report. http://www.hanosimex.com.vn.

[27] March 29 Textile Garment Joint Stock Company, Financial report. http://www.hachiba.com.vn.

[28] G. HOME Textile Investment Joint Stock Company, Financial report. http://www.cozin.com.vn.

[29] Viet Tien garment joint stock corporation, Financial report. http://www.viettien.com.vn.

[30] G. D. Li, S. Masuda, and M. Nagai, "An optimal prediction model using taylor approximation method," The Journal of Grey System, vol. 11, pp. 91-100, 2011.

[31] J. L. Deng, "Introduction to grey system theory," The Journal of Grey System, vol. 1, no. 1, pp. 1-24, 1989.

[32] M. Yu, C. Wang, and N. Ho, "A grey forecasting approach for the sustainability performance of logistics companies," Sustainability, vol. 8, no. 9, p. 866, 2016.

[33] C. D. Lewis, "Industrial and Business Forecasting Method," Journal of Forecasting, vol. 2, no. 2, pp. 194-196, 1982.

[34] K. Tone, "A slacks-based measure of efficiency in data envelopment analysis," European Journal of Operational Research, vol. 130, no. 3, pp. 498-509, 2001.

[35] E. Düzakin and H. Düzakin, "Measuring the performance of manufacturing firms with super slacks based model of data envelopment analysis: an application of 500 major industrial enterprises in Turkey," European Journal of Operational Research, vol. 182, no. 3, pp. 1412-1432, 2007.

[36] K. Tone, "A slacks-based measure of super-efficiency in data envelopment analysis," European Journal of Operational Research, vol. 143, no. 1, pp. 32-41, 2002.

[37] F.-Y. Lo, C.-F. Chien, and J. T. Lin, "A DEA study to evaluate the relative efficiency and investigate the district reorganization of the Taiwan Power Company," IEEE Transactions on Power Systems, vol. 16, no. 1, pp. 170-178, 2001.

[38] H. Yapıcı and N. Çetinkaya, "An improved particle swarm optimization algorithm using eagle strategy for power loss minimization," Mathematical Problems in Engineering, vol. 2017, Article ID 1063045, 11 pages, 2017. 


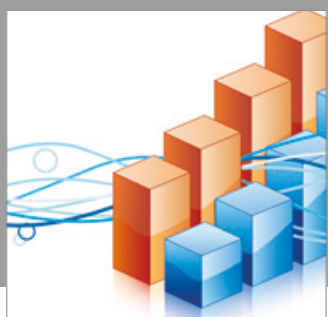

Advances in

Operations Research

vatersals

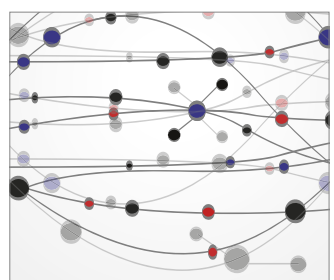

\section{The Scientific} World Journal
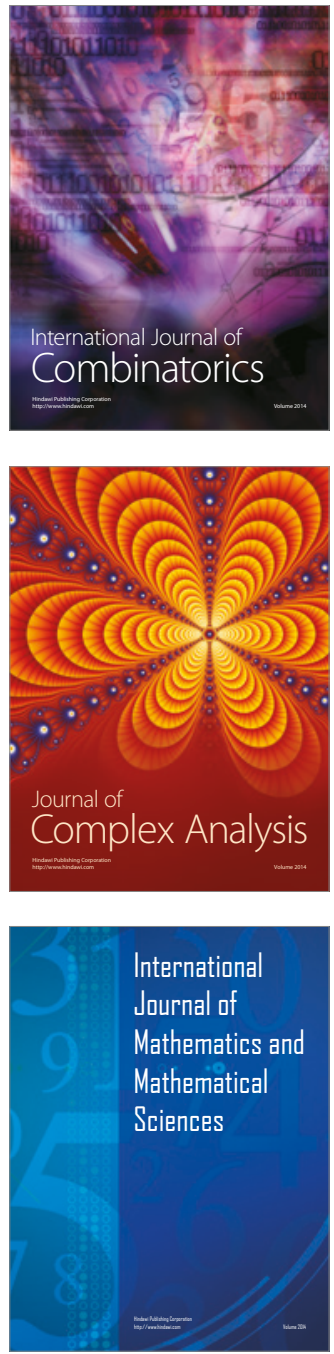
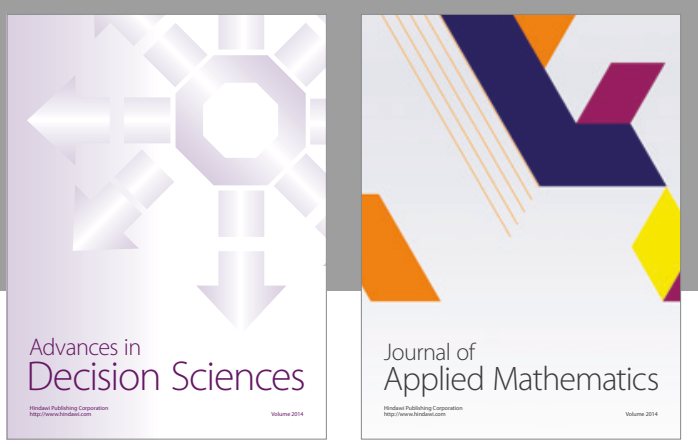

Algebra

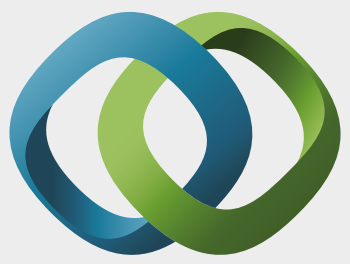

\section{Hindawi}

Submit your manuscripts at

https://www.hindawi.com
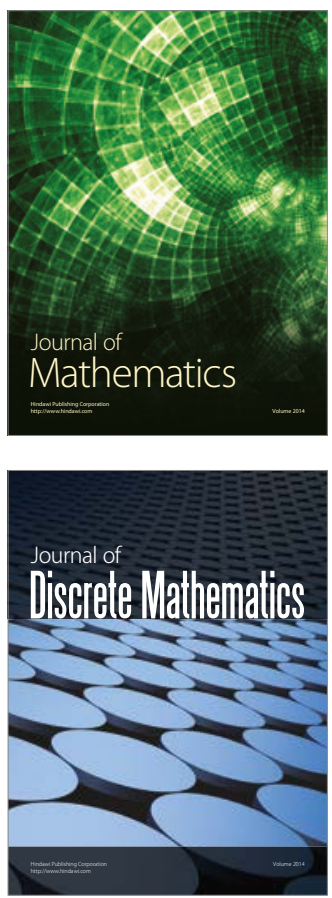

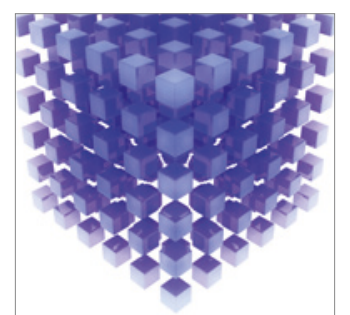

Mathematical Problems in Engineering
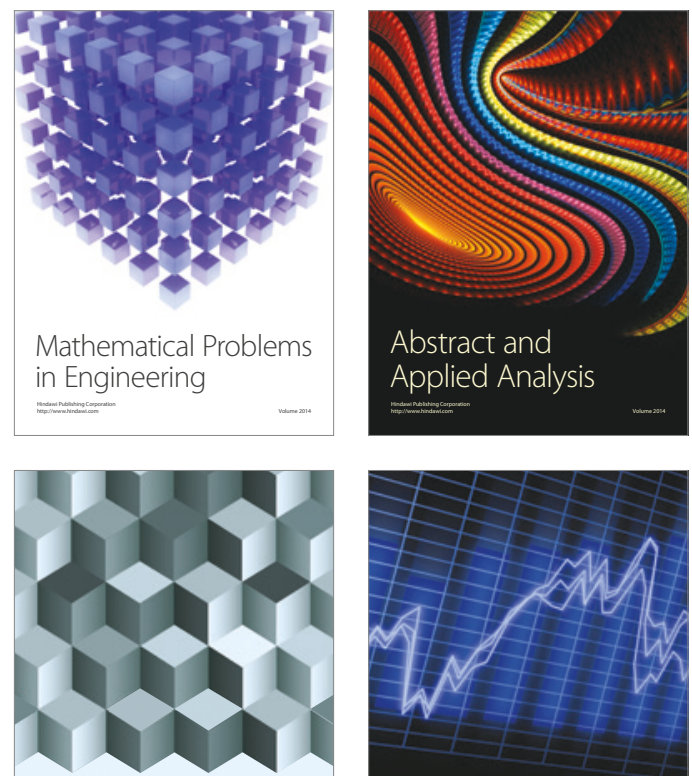

Journal of

Function Spaces

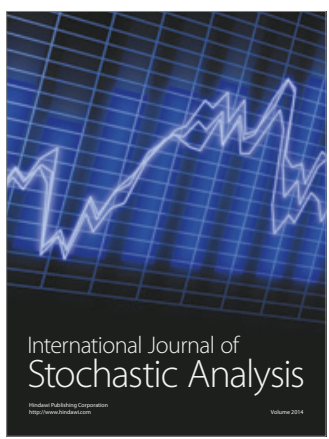

Probability and Statistics
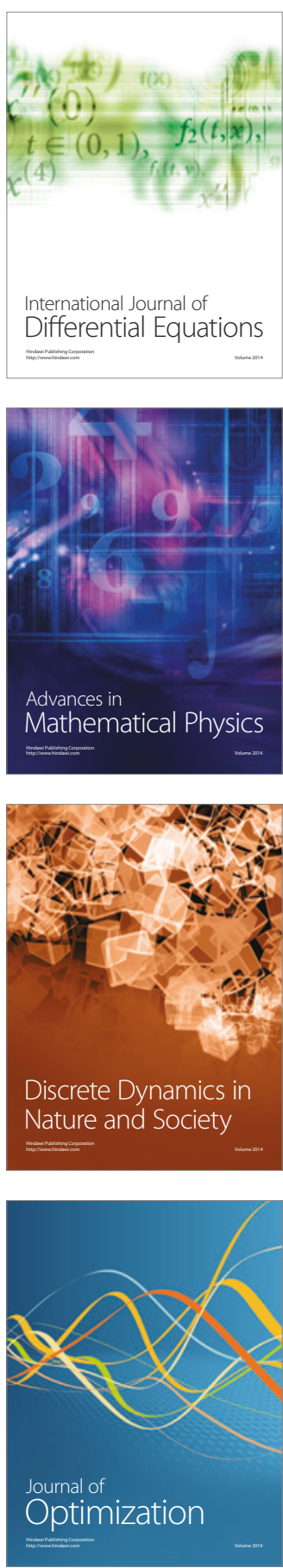